\title{
Trend Analysis and Growth Rate of Area, Production and Productivity of Marigold Flower in Ratlam Districts of Madhya Pradesh
}

\author{
Yamini Raut* and A.K. Sarawgi
}

Department of Agricultural Economics and Farm management, College of Agriculture, Jawaharlal Nehru Krishi Vishwa Vidhyalaya, Jabalpur-482004 Madhya Pradesh (India)

*Corresponding author

\section{A B S T R A C T}

\section{Keywords \\ Marigold, Trend analysis, Simple growth rate}

\section{Article Info}

Accepted:

10 May 2019

Available Online:

10 June 2019
The present study was conducted in Ratlam district of Madhya Pradesh, with the objective to know the trend value and growth rate of area, production and productivity of marigold flower. Madhya Pradesh has 52 districts out of them Ratlam district cover highest area of marigold i.e. approximately 28 percent. The result of trend and growth of area, production and productivity was found positive in all blocks of Ratlam district but, in case of Alot and Sailana blocks, the trend value and simple growth rate (SGR) of area and production was observed negative. Whereas the result for Ratlam district was found positive and the slope (b) 656.49 with 1 per cent level of significance. In regard to production of marigold, it was found positive and the positive slope (b) is 6320.99 with high level of significance. In case of productivity, it was observed positive and the positive slope (b) is 125.67 with 5 per cent level of significance. The simple growth rate was found positive during the study period. The simple growth rate was found to be 27.68 percent in area fallowed by 28.08 percent in production and 0.64 percent in productivity.

\section{Introduction}

Marigold word is derived from Mary's gold. Marigold belongs to asterales order and asteraceae family. They are kept up in gardens throughout world. Traditionally marigold is used to help minor burns, wounds and other skin problems. The flower petals may be utilized as an herbal imbuement and for eyewash. Marigold petals add colour and flavor in different dishes like stews, soups, pudding and salads. The marigold is probably the most well-known plant for repelling insects. Marigold is one of the most important commercially exploited flowers in India, which is widely grown for their aesthetic, economic, religious and social value. Marigold is an important loose flower crop which occupies a special place in flower cultivation due to its hardiness and easy cultivation, its alternative quality has attracted the attention of flower growers. The area under the marigold cultivation in India is about 68.33 thousand ha with a production of 607.97 thousand MT in 2016-17 (DAC \& FW). Madhya Pradesh is a major marigold 
producing a state in India. In Madhya Pradesh marigold flower is mainly cultivated in Bhopal, Betul, Indore Ratlam and Ujjain district. Ratlam district covers the largest area of marigold i.e. 28.42 per cent. By keeping in view of this information, trend and growth rate of the marigold flower was estimated in Ratlam district of Madhya Pradesh.

\section{Materials and Methods}

\section{Nature, source and period of study}

Ratlam district comprises of six blocks to be specific: Jaora, Piploda, Ratlam, Alot, Sailana and Bajna. To get a comprehensive picture of trend and growth rate in the area, production and productivity of marigold, block-wise time series secondary data for the period of ten years was collected. The source of the data was secondary in nature and was mainly collected from the district horticulture department of Ratlam.

All the collected secondary data was related to the agriculture years from 2008-09 to 201718.

\section{Analytical tools}

Trend analysis and growth rate: To study the trend analysis of Marigold flower in Ratlam district of Madhya Pradesh, the trend analysis was carried out using least-square method. The following liner regression equation was used.

$\mathrm{Y}=\mathrm{a} \pm \mathrm{b} \times$

Where,

$\mathrm{Y}=$ Area / production / yield

$\mathrm{a}=$ constant or intercept value

$\mathrm{b}=$ regression coefficient

$\mathrm{x}=$ Time period

\section{Simple growth rate}

To estimate the simple growth rate following formula was used.
$\mathrm{SGR}=\mathrm{b} / \overline{\mathrm{y}} \times 100$

Where,

$\mathrm{b}=$ Reg. coefficient

$\overline{\mathrm{Y}}=\sum \mathrm{y} / \mathrm{n}$

\section{Results and Discussion}

The block wise trend and simple growth rate of area, production and productivity of marigold flower are presented in below tables.

Table 1 shows the value of the trend coefficient of the area of marigold flower in jaora was found positive. The trend value in the production of marigold flower was found positive, for productivity trend value was positive and significant at 5 per cent of level of significance.

From table 1 it was observed that the value of simple growth rate of area, production and productivity was positive. Thus it could be concluded that the result of trend and SGR for Jaora block are positive.

From table 2 it can be concluded that the trend coefficient of area, production and productivity of marigold flower in Piploda block was found positive. Regarding SGR, it was observed that the value of SGR is positive for area, production and productivity.

Table 3 has indicated the trend and growth of area, production and productivity of marigold in Ratlam block. As regard, the trend in area and production was found positive and significant at 1 per cent. In case of productivity of marigold, the positive slope was observed. SGR was observed positive in area, production and productivity of marigold flower in Ratlam block.

This table 4 shows the trend value and SGR of area, production and productivity of marigold flower in Alot block. It could be concluded that the slop of area and production 
was found negative but as far as the productivity of marigold flower, a positive slop was observed. Simple growth rate, for area and production was observed negative where as for productivity it was found positive.

An analysis of the table 5 proved that the trend value and SGR for area and production of marigold flower in sailana was found negative. However for productivity, the trend value and SGR was positive.

Table 6 show the trend value and growth rate of marigold flower in Bajan block. As evident from the data, the trend value of area, production and productivity of marigold flower was found in a positive slope. As far as SGR was observed, it too was found positive for area, production and productivity.

Table.1 Trend value and growth rate of Jaora block of Ratlam district.

\begin{tabular}{|c|c|c|c|c|c|c|c|c|c|}
\hline \multicolumn{1}{c|}{ Area $=$ Ha. , Production = MT, Productivity $=\mathrm{Kg} / \mathrm{ha}}$. \\
\begin{tabular}{|c|c|c|c|c|c|c|c|} 
Name \\
of \\
block
\end{tabular} & $\begin{array}{c}\text { Area } \\
\text { Constant } \\
\text { (a) }\end{array}$ & $\begin{array}{c}\text { Regression } \\
\text { coefficient } \\
\text { (b) }\end{array}$ & $\begin{array}{c}\text { SGR } \\
(\%)\end{array}$ & $\begin{array}{c}\text { Constant } \\
\text { (a) }\end{array}$ & $\begin{array}{c}\text { Regression } \\
\text { coefficient } \\
\text { (b) }\end{array}$ & $\begin{array}{c}\text { SGR } \\
(\%)\end{array}$ & $\begin{array}{c}\text { Constant } \\
\text { (a) }\end{array}$ & $\begin{array}{c}\text { coefficient } \\
\text { (b) }\end{array}$ & $\begin{array}{c}\text { SGR } \\
(\%)\end{array}$ \\
\hline Jaora & 117.87 & 4.04 & 2.89 & 833.7 & 76.12 & 5.76 & 7392.2 & $307.14 * *$ & 3.28 \\
\hline
\end{tabular}

Table.2 Trend value and growth rate of Piploda block of Ratlam district

Area $=$ Ha, Production $=$ MT, Productivity $=\mathrm{Kg} / \mathrm{ha}$.

\begin{tabular}{|c|c|c|c|c|c|c|c|c|c|}
\hline \multirow{2}{*}{$\begin{array}{c}\text { Name } \\
\text { of } \\
\text { block }\end{array}$} & \multicolumn{3}{|c|}{ Area } & \multicolumn{3}{|c|}{ Production } & \multicolumn{3}{|c|}{ Productivity } \\
\hline & $\begin{array}{c}\text { Constant } \\
\text { (a) }\end{array}$ & $\begin{array}{l}\text { Regression } \\
\text { coefficient } \\
\text { (b) }\end{array}$ & $\begin{array}{l}\text { SGR } \\
(\%)\end{array}$ & $\begin{array}{c}\text { Constant } \\
\text { (a) }\end{array}$ & $\begin{array}{l}\text { Regression } \\
\text { coefficient } \\
\text { (b) }\end{array}$ & $\begin{array}{c}\text { SGR } \\
(\%)\end{array}$ & $\begin{array}{c}\text { Constant } \\
\text { (a) }\end{array}$ & $\begin{array}{c}\text { coefficient } \\
\text { (b) }\end{array}$ & $\begin{array}{l}\text { SGR } \\
(\%)\end{array}$ \\
\hline Piploda & 96.67 & 1.88 & 1.76 & 763.30 & 42.83 & 4.13 & 8377.43 & 121 & 1.32 \\
\hline
\end{tabular}

Table.3 Trend value and growth rate of Ratlam block of Ratlam district

Area $=$ Ha, Production $=$ MT, Productivity $=\mathrm{Kg} / \mathrm{ha}$.

\begin{tabular}{|c|c|c|c|c|c|c|c|c|c|}
\hline \multirow{2}{*}{$\begin{array}{c}\text { Name } \\
\text { of } \\
\text { block }\end{array}$} & \multicolumn{3}{|c|}{ Area } & \multicolumn{3}{|c|}{ Production } & \multicolumn{3}{|c|}{ Productivity } \\
\hline & $\begin{array}{c}\text { Constant } \\
\text { (a) }\end{array}$ & $\begin{array}{c}\text { Regression } \\
\text { coefficient } \\
\text { (b) }\end{array}$ & $\begin{array}{l}\text { SGR } \\
(\%)\end{array}$ & $\begin{array}{c}\text { Constant } \\
\text { (a) }\end{array}$ & $\begin{array}{l}\text { Regression } \\
\text { coefficient } \\
\text { (b) }\end{array}$ & $\begin{array}{l}\text { SGR } \\
(\%)\end{array}$ & $\begin{array}{l}\text { Constant } \\
\text { (a) }\end{array}$ & $\begin{array}{c}\text { coefficient } \\
\text { (b) }\end{array}$ & $\begin{array}{l}\text { SGR } \\
(\%)\end{array}$ \\
\hline Ratlam & -1656.33 & $645.21 * * *$ & 33.69 & -21748.3 & $6178.05 * * *$ & 34.73 & 8652.75 & 73.59 & 0.81 \\
\hline
\end{tabular}


Table.4 Trend value and growth rate of Alot block of Ratlam district

\begin{tabular}{|c|c|c|c|c|c|c|c|c|c|}
\hline \multicolumn{1}{|c|}{ Area = Ha. , Production = MT, Productivity = Kg/ha. } \\
\hline $\begin{array}{c}\text { Name } \\
\text { of } \\
\text { block }\end{array}$ & \begin{tabular}{c} 
Area \\
\cline { 3 - 11 } \\
Constant \\
(a)
\end{tabular} & $\begin{array}{c}\text { Regression } \\
\text { coefficient } \\
\text { (b) }\end{array}$ & $\begin{array}{c}\text { SGR } \\
(\%)\end{array}$ & $\begin{array}{c}\text { Constant } \\
\text { (a) }\end{array}$ & $\begin{array}{c}\text { Regression } \\
\text { coefficient } \\
\text { (b) }\end{array}$ & $\begin{array}{c}\text { SGR } \\
(\%)\end{array}$ & $\begin{array}{c}\text { Constant } \\
\text { (a) }\end{array}$ & $\begin{array}{c}\text { coefficient } \\
\text { (b) }\end{array}$ & $\begin{array}{c}\text { SGR } \\
(\%)\end{array}$ \\
\hline Alot & 120.73 & -6.61 & -7.83 & 1605.20 & -36.08 & -4.32 & 8460.98 & 128.7 & 1.38 \\
\hline
\end{tabular}

Table.5 Trend value and growth rate of Sailana block of Ratlam district

Area $=$ Ha., Production $=$ MT, Productivity $=\mathrm{Kg} / \mathrm{ha}$.

\begin{tabular}{|c|c|c|c|c|c|c|c|c|c|}
\hline \multirow{2}{*}{$\begin{array}{c}\text { Name } \\
\text { of } \\
\text { block }\end{array}$} & \multicolumn{3}{|c|}{ Area } & \multicolumn{3}{|c|}{ Production } & \multicolumn{3}{|c|}{ Productivity } \\
\hline & $\begin{array}{c}\text { Constant } \\
\text { (a) }\end{array}$ & $\begin{array}{l}\text { Regression } \\
\text { coefficient } \\
\text { (b) }\end{array}$ & $\begin{array}{l}\text { SGR } \\
(\%)\end{array}$ & $\begin{array}{c}\text { Constant } \\
\text { (a) }\end{array}$ & $\begin{array}{l}\text { Regression } \\
\text { coefficient } \\
\text { (b) }\end{array}$ & $\begin{array}{c}\text { SGR } \\
(\%)\end{array}$ & $\begin{array}{c}\text { Constant } \\
\text { (a) }\end{array}$ & $\begin{array}{l}\text { coefficient } \\
\text { (b) }\end{array}$ & $\begin{array}{l}\text { SGR } \\
(\%)\end{array}$ \\
\hline Sailana & 53.27 & -1.23 & -2.65 & 437.54 & -2.38 & -5.02 & 7277.23 & 312.41 & 3.37 \\
\hline
\end{tabular}

Table.6 Trend value and growth rate of Bajan block of Ratlam district.

\begin{tabular}{|c|c|c|c|c|c|c|c|c|c|}
\hline \multicolumn{10}{c|}{ Area = Ha. , Production = MT, Productivity $=\mathrm{Kg} / \mathrm{ha}}$. \\
\begin{tabular}{|c|c|c|c|c|c|c|c|} 
Name \\
of \\
block
\end{tabular} & $\begin{array}{c}\text { Area } \\
\text { Constant } \\
\text { (a) }\end{array}$ & $\begin{array}{c}\text { Regression } \\
\text { coefficient } \\
\text { (b) }\end{array}$ & $\begin{array}{c}\text { SGR } \\
(\%)\end{array}$ & $\begin{array}{c}\text { Constant } \\
\text { (a) }\end{array}$ & $\begin{array}{c}\text { Regression } \\
\text { coefficient } \\
\text { (b) }\end{array}$ & $\begin{array}{c}\text { SGR } \\
(\%)\end{array}$ & $\begin{array}{c}\text { Constant } \\
\text { (a) }\end{array}$ & $\begin{array}{c}\text { coefficient } \\
\text { (b) }\end{array}$ & $\begin{array}{c}\text { SGR } \\
(\%)\end{array}$ \\
\hline Bajan & 28.60 & 4.28 & 8.32 & 178.08 & 43.35 & 9.16 & 8161.66 & 77.03 & 0.77 \\
\hline
\end{tabular}

Table.7 Trend value and growth rate of Ratlam district

Area $=$ Ha., Production $=$ MT, Productivity $=\mathrm{Kg} / \mathrm{ha}$.

\begin{tabular}{|l|c|c|c|c|c|c|c|c|c|}
\hline \multirow{2}{*}{ District } & \multicolumn{3}{|c|}{ Area } & \multicolumn{3}{c|}{ Production } & \multicolumn{3}{c|}{ Productivity } \\
\cline { 2 - 9 } & $\begin{array}{c}\text { Constant } \\
\text { (a) }\end{array}$ & $\begin{array}{c}\text { Regression } \\
\text { coefficient } \\
\text { (b) }\end{array}$ & $\begin{array}{c}\text { SGR } \\
(\%)\end{array}$ & $\begin{array}{c}\text { Constant } \\
\text { (a) }\end{array}$ & $\begin{array}{c}\text { Regression } \\
\text { coefficient } \\
\text { (b) }\end{array}$ & $\begin{array}{c}\text { SGR } \\
(\%)\end{array}$ & $\begin{array}{c}\text { Constant } \\
\text { (a) }\end{array}$ & $\begin{array}{c}\text { coefficient } \\
\text { (b) }\end{array}$ & $\begin{array}{c}\text { SGR } \\
(\%)\end{array}$ \\
\hline Ratlam & -1239.20 & $656.49 * * *$ & 27.68 & 11192.67 & $6320.99 * * *$ & 28.08 & 8466.67 & $125.67 * *$ & 0.64 \\
\hline
\end{tabular}


Table 7 shows the trend value and SGR of area, production and productivity of Ratlam district. The trend value of the area of marigold in Ratlam district was found positive and the slope (b) 656.49 with 1 per cent level of significance. In regard to production of marigold, it was found positive and the positive slope (b) is 6320.99 with high level of significance. In case of productivity, it was observed positive and the positive slope (b) is 125.67 with 5 per cent level of significance. Observing the simple growth rate of area, production and productivity, it was found positive during the study period.

Graphically representation of trend value of marigold flower area, production and productivity in Ratlam district.

\section{References}

Anonymous, (2017). Horticulture crop estimate, Department of Agriculture \& Farmers Welfare (DAC\&FW), Government of India, New Delhi, India.

Patel, Vimal (2017) "Economic Analysis of Commercial Flower Cultivation in Khandwa district of Madhya Pradesh" Thesis of M.Sc. (Ag), RVSKVV.

Visgwakarma, Rajeshwari (2013) "Study On Growth Rates, Profatibility And Marketing Pattren Of Marigold Flower In Chhindwara District Of Madhya Pradesh" Thesis of M.SC. (Ag), JNKVV.

\section{How to cite this article:}

Yamini Raut and Sarawgi, A.K. 2019. Trend Analysis and Growth Rate of Area, Production and Productivity of Marigold Flower in Ratlam Districts of Madhya Pradesh. Int.J.Curr.Microbiol.App.Sci. 8(06): 927-931. doi: https://doi.org/10.20546/ijcmas.2019.806.111 